\title{
The Relationship of Socio-Economic with Nutritional Status in Toddlers in Meureubo Sub-District West Aceh Regency
}

\author{
${ }^{1}$ Khairunnas Khairunnas, ${ }^{2}$ Arfah Husna, ${ }^{3}$ Marniati Marniati \\ ${ }^{1}$ Public Health Faculty, Teuku Umar University, Indonesia, khairunnas@utu.ac.id \\ ${ }^{2}$ Public Health Faculty, Teuku Umar University, Indonesia, arfahhusna@utu.ac.id \\ ${ }^{3}$ Public Health Faculty, Teuku Umar University, Indonesia, marniati@utu.ac.id \\ Coresponding author : Khairunnas, e-mail : khairunnas@utu.ac.id
}

\begin{abstract}
Children's health and growth are issues that need continuous attention by various parties, such as the government and family. As a result of malnutrition status in infancy can cause growth retardation, causing toddlers to be lazy to do activities related to energy production, disruption of the toddler's immune system so they are susceptible to infectious diseases, inhibited optimal brain growth, and changes in behavior exhibited by toddlers such as not calm, easy crying and its ongoing impact is apathetic behavior. Based on the preliminary survey in the Meurebo SubDistrict, West Aceh Regency, there were 4 toddlers suffering from malnutrition and 11 people with underweight nutritional status. The aims of study was to look at the socio-economic relationship with nutritional status of toddlers. This study uses quantitative research with a cross-sectional approach using a chi-square test with a standard error of 0.05 . The population of this study were 46 peoples with those taken based on sample distribution. The results obtained by the value of sig $=0.007$ which means smaller than the value of $\alpha=0.05$, so it can be concluded a significant relationship between socio-economic and nutritional status of toddler.
\end{abstract}

\section{ARTICLE INFORMATION}

Submitted: $08 / 01 / 2020$

Revised: $16 / 02 / 2020$

Accepted: 21/04/2020

Published Online : 15/05/2020

Keywords:

Nutritional Status

Socio-Economic

How to cite this article: Khairunnas, K., Husna, A., Marniati, M. (2020). The Relationship of Socio-Economic with Nutritional Status in Toddlers in Meureubo Sub-District, West Aceh Regency. JNS : Journal of Nutrition Science, 1(1), 6-10.

\section{Introduction}

Health development is an integrated part of human resource development in promoting a developed and independent nation as well as physical and spiritual prosperity. One of the characteristics of an advanced nation is a nation that has a high degree of health. The ranking of the degree of public health is marked by decreasing the number of infant and maternal mortality rates, improving the nutritional status of the community and increasing life expectancy. (Adisasmito, 2012).

The malnutrition problem is generally caused by lack of food supplies, lack of good environmental quality, poverty, balanced menus, lack of community knowledge about nutrition, and health as well as the presence of poor nutrition areas (iodine). Children's health and growth are issues that need continuous attention by various parties, such as the government and family. Children are the successor to the nation, in their hands the future of this nation will be determined. If a nation has children who are physically and mentally healthy, it will create quality human resources, intelligent and productive. The decline in the quality of a generation can be prevented by saving them from physical, mental and intellectual health disorders. It must be admitted that the concern for parents towards their children is very large. Many factors affect a person's intelligence level, including nutritional factors. (Setiabudhi, T.2012).

As a result of malnutrition status in infancy can cause growth retardation, causing toddlers to be lazy to do activities related to energy production, disruption of the toddler's immune system so that 
they are susceptible to infectious diseases, inhibited optimal brain growth, and changes in behavior exhibited by toddlers such as not calm, easy crying and its ongoing impact is apathetic behavior. (Wira Mutika.2018).

One way to measure nutritional conditions is by assessing nutritional status. Nutritional status is an expression of a state of equilibrium in the form of certain variables or an embodiment of nutritionure in the form of certain variables. Nutritional status is determined by several factors, according to Unicef in Supariasa (2012).

Poor nutritional status in children under five is caused by several factors, one of which is food intake as a direct cause and maternal skills about nutrition in children under five as the main problem. Food intake or consumption can directly affect a person's nutritional state or nutritional status (Supariasa, et al, 2012).

In the Global Nutrition Report in 2017 showed nutritional status problems in the world including the prevalence of wasting (thin) 52 million children (8\%), stunting (short) 115 million children (23\%), and overweight 4 million children (6\%) with a target 100\% (UNICEF and WHO, 2017). In 2019 One in three children under five in the world experience malnutrition and not develop properly. A large number of children suffer from bad food and the food system that makes them fail. Around 200 million children under five suffer from malnutrition or being overweight (overweight / obese). Meanwhile, one in three children (aged between six months and one year), globally does not get proper food. With a target of $17 \%$ (UNICEF 2019).

Based on the results of the Basic Health Research (Riskesdas 2018) the Ministry of Health 2018 showed $17.7 \%$ of infants under 5 years old (toddlers) were still experiencing nutritional problems. This figure consisted of toddlers who experienced malnutrition of $3.9 \%$ and those suffering from malnutrition of $17.8 \%$. Where underweight underweight children have a target of $17 \%$ and wasting toddlers at 9\%. (Health Office, 2018).

The prevalence of nutritional status in Aceh Province with BB / TB measurement is $12.8 \%$ while based on BB / U measurements $24.8 \%$ with a target of $100 \%$ where the number of children under five is 568,899 children, 149 children under five suffer from malnutrition, and children with underweight status $18.8 \%$, the nutritional status of under-fives is $1.1 \%$ and under-fives with a good nutritional status of $74.1 \%$ (Aceh Provincial Health Office with Poltekkes, 2017).
Whereas in 2018 the number of toddlers aged $0-4$ years old boys as many as 290,035 and women 278,907 which under five suffer from malnutrition and lack of $18 \%$ with a target of 100 per 1000 population. Whereas in 2019 , there was a target of $28 \%$ in February 2019, there were 3,125 children suffering from malnutrition and also identified as many as 12,000 children under five who were suffering from malnutrition. (Aceh Health Propil, 2018).

Based on the observation of the West Aceh Health Service in 2019 in West Aceh until August there were cases of malnutrition in which there were 8 cases in Kuta Padang health center, Drien Rampak health center 4 cases, Pante Cermen health center 10 cases, Arongan Lambalek health center 8 cases, Meurebo health center 14 Cases and Health Centers Cot Seumareng 1 Case, and in 2019 the most common cases of malnutrition were found in the Meurebo Health Center, Meurebo District, West Aceh Regency which has a target of $17 \%$. (West Aceh Health Service, 2019).

Based on the preliminary survey conducted by the author, in the Work Area of the Meurebo Public Health Center, West Aceh Regency, there were 4 toddlers who suffered from malnutrition and of which 2 of the toddlers were cured and 2 toddlers were still in care. While toddlers suffering from malnutrition status there are several cases in various villages in the Meurebo working area, which in Sumber Batu Village have 1 case, Bukit Jaya village 1 case, Peunaga Baro village 1 case, Pasie Mesjit Gampong 1 case, Pasie Mesdit village ADB 1 Case, Paya Baro 2 Case, Bukit Jaya 1 Case, Buloh 1 Case, Pasie Pinag 1 Case, Mestu 2 Case, Ranto Panjang Barat 1 Case, and Pasie Aceh Baroh Village 1 Case.

Based on the results of interviews conducted on 5 mothers who have toddlers, 3 of which mothers have toddlers with undernourished status, of which 3 mothers of toddlers can be concluded that undernutrition experienced by their toddlers is defined by economic factors one of which. Based on the description above, the authors conducted a study entitled "The Relationship of Socio-Economic with Nutrition Status in Toddlers in Meureubo SubDistrict, West Aceh Regency".

\section{Method}

This research uses quantitative research with cross sectional approach by means of univariate and bivariate analysis using chi-square test with a standard error of 0.05 . The population of this study was 46 people with those taken based on sample 
distribution. sampling technique using total sampling technique, which is taking all members of the population that is as many as 46 . This research was conducted in December 2019 in the Work Area of the Meureubo Health Center in West Aceh Regency.

\section{Results}

Univariate Analysis

Toddler Frequency Distribution Based on Gender

Table 1. Frequency Distribution by Gender Toddler

\begin{tabular}{lcc}
\hline \multicolumn{1}{c}{ Gender } & Frequency & \% \\
\hline Male & 23 & 50.0 \\
Female & 23 & 50.0 \\
\hline \multicolumn{1}{c}{ Total } & $\mathbf{4 6}$ & 100 \\
\hline
\end{tabular}

Based on the analysis of the data above, it can be concluded that toddlers who are male are 23 people $(50.0 \%)$, while toddlers who are female are 23 people $(50.0 \%)$.

\section{Toddler Frequency Distribution Based on Nutrition Status}

Table 2. Frequency Distribution Based on Toddler Nutrition Status

\section{Bivariate Analysis}

Table 4. Relationship of Socio-economic with Nutrition Status in Toddlers

\begin{tabular}{|c|c|c|c|c|c|c|c|c|c|}
\hline \multirow{3}{*}{ Social-Economy } & \multicolumn{6}{|c|}{ Nutritional Status } & \multirow{2}{*}{\multicolumn{2}{|c|}{ Total }} & \multirow{3}{*}{$\mathbf{P}_{\text {value }}$} \\
\hline & \multicolumn{2}{|c|}{ Good Nutrition } & \multicolumn{2}{|c|}{ Malnutrition } & \multicolumn{2}{|c|}{$\begin{array}{c}\text { Poor } \\
\text { Nutrition }\end{array}$} & & & \\
\hline & f & $\%$ & f & $\%$ & $\mathbf{f}$ & $\%$ & f & $\%$ & \\
\hline High & 15 & 41.7 & 14 & 38.9 & 7 & 19.4 & 36 & 100 & \multirow{3}{*}{0.007} \\
\hline Low & 8 & 80.0 & 2 & 20.0 & 0 & 0.0 & 10 & 100 & \\
\hline Total & 23 & 50.0 & 16 & 34.8 & 7 & 15.2 & 46 & 100 & \\
\hline
\end{tabular}

From the above table it can be stated that respondents with low economic status who have toddlers with good nutritional status are 10 toddlers $(32.3 \%)$, while respondents with low economic status with poor nutritional status are 14 toddlers (45.2\%) and respondents with economic status Low toddlers who have poor nutritional status are absent.

Whereas respondents with high economy who have good nutritional status of toddlers are 8 toddlers $(80.0 \%)$ and respondents with high economic toddlers $(20.0 \%)$, and respondents with high economy with toddlers with poor nutritional status are absent.

From the results of the chi square test, the sig $=$ 0.007 value is obtained which is smaller than the toddlers who have undernourished status are 2

\begin{tabular}{lcc}
\hline Nutritional status & Frequency & \% \\
\hline Good Nutrition & 23 & 50.0 \\
Malnutrition & 16 & 34.8 \\
Poor Nutrition & 7 & 15.2 \\
\hline \multicolumn{1}{c}{ Total } & $\mathbf{4 6}$ & $\mathbf{1 0 0}$ \\
\hline Based on the analysis table above, it can be
\end{tabular}
stated that the most toddlers with good nutritional status are 23 toddlers (50.0\%), while the lowest number of toddlers with poor nutritional status is 7 toddlers $(15.2 \%)$.

\section{Distribution of Respondents Frequency Based on Social-Economy}

Table 3. Frequency Distribution Based on Social Economy

\begin{tabular}{|c|c|c|}
\hline Social-Economy & Frequency & Persen \% \\
\hline High & 10 & 21.7 \\
\hline Low & 36 & 78.3 \\
\hline Total & 46 & 100 \\
\hline
\end{tabular}

Based on the above data it can be seen that respondents who have high socio-economic are 10 people $(21.7 \%)$ while respondents who have low socio-economic are 36 people (78.3\%). value of $\alpha=0.05$, and it can be concluded that there is an influence between socioeconomic and Toddler Nutrition Status in Meureubo Sub-District, West Aceh Regency.

\section{Discussion}

From the results of research conducted the influence of socioeconomic factors with the Nutrition Status of Toddlers in the Work Area of the Meurebo Health Center, West Aceh Regency.

From the results of the regression test, a sig value of 0.007 is obtained, which is smaller than the value of $\alpha=0.05$, and it can be stated that there is an influence between socioeconomic and Toddler Nutrition Status in the Work Area of Meurebo Health Center, West Aceh Regency. 
Income is the amount of money received from a person's activities in carrying out his work, where the specified income standard is in accordance with the Provincial MSE, if access to food at the household level is disrupted, mainly due to poverty, malnutrition will definitely emerge. Poverty or low family income greatly influences the adequacy of family nutrition (Hertien.2018).

This research is also supported by previous research by Hertien Novi Roficha (2018). Chi-square test results obtained $p=0.026$ with significance level $\alpha=0.05$. This shows the value of $p<\alpha$, meaning there is an influence between parental income and the nutritional status of children under five.

\section{Conclusion}

From the results of research conducted showed a significant relationship between socioeconomic with Nutrition Status in Toddlers in Meureubo SubDistrict, West Aceh Regency.

\section{Acknowledgement}

The researcher would like to thank the Head of the Meureubo Community Health Center who helped during the data collection process in this study.

\section{Author Contribution and Competing Interest}

During the process of collecting, processing and analyzing data to the interpretation of all writers, they contributed and ensured that there were no conflicts of interest related to this text.

\section{Publisher's Note}

JONS : Jurnal Of Nutritien Science remains neutral with regard to jurisdictional claims in published institutional affilition.

\section{References}

Adisasmito,Wiku. 2012. Sistem Kesehatan,Edisi I, Jakarta: Rineka Cipta.

Setiabudhi, T. 2012. Gizi Untuk Proses Tumbuh Kembang Anak.ECG, Jakarta:

Budiman, A. 2013. Hububgan Antara Komsumsi Makanan,Pestasi Belajar,Dengan Status Gizi Dan Kadar Hb Anak Jalanan Di Bawah Asuhan Beberapa Rumah Singgah Yang Ada Di Yogyakarta.Tesis Universitas Gajah Mada.

Dinas Kesehatan Provinsi Aceh, 2013.Profil kesehatan aceh.

Suhardjo, 2013. Perencanaan Pangan Dan Gizi,Bumi Aksara, Jakarta.
Supriasa, I Nyoman. 2012. Penilaian Status Gizi. Penerbit buku kedoktoran (EGC).Jakarta.

Dharmayekti, Endang . 2011. Manajemen Rumah Tangga.UNY: Yogyakarta.

Kusin, J.A. 2011. Masalah Kesehatan Di Indonesia Ilmu Ilmu Sosial Dalam Pertumbuhan Dan Kesehatan. PT Gramedia: Jakarta.

Etika, Proverawati, 2010.Pengukuran Status Gizi. Erlanga: Jakarta.

Kemenkes RI. 2017. Profil Kesehata Indonesia Tahun 2016. Jakarta

Dinas Kesehatan Provinsi Aceh Dengan Poltekkes. 2017. Studi Monitoring Dan Evaluasi Program Gizi PSG\&PKG. Aceh.

Dinas Kesehatan Aceh Barat. 2018. Pemantauan Kasus Gizi Kurang Dinas Kesehatan Kabupaten/Kota Tahun 2018. Aceh Barat.

Nelfi Sarlis, Cindy Netta Ivanna. 2018. Faktor Berhubungan Dengan Status Gizi Balita Di Puskesmas Sidomulyo Pekanbaru Tahun 2016. Pekan Baru.

Wira Mutika. 2018. Analisis Permasalahan Status Gizi Kurang Pada Balita Di Puskesmas

Teupah Selatan Kabupaten Simeuleu.

Supariasa, Bakrie, B., Fajar, I. 2012. Penilaian Status Gizi. Jakarta: EGC.

Gustiva Sari.2016. Hubungan Pola Makan Dengan Status Gizi Anak Usia 3-5 Tahun Di Wilayah Kerja Puskesmas Nanggalo Padang.

Mubarak.2018. Analisis Faktor yang Berhubungan dengan Status Gizi Anak Balita di Wilayah Pesisir Kecamatan Soropia.

Hertien Novi Roficha. 2018. Pengetahuan Gizi Ibu Dan Sosial Ekonomi Keluarga Terhadap Status Gizi Balita Umur 6-24 Bulan.

Sri Wahyu Andayani. 2013. Hubungan Konsumsi Makan Dan Status Gizi Dengan Prestasi Belajar Siswa. Yogyakarta.

Gusti Rengga Dinata. 2015. Daya Beli Kebutuhan Dasar Pangan Terhadap Status

Gizi Balita Usia 3-5 Tahun (Studi Di Desa Temboro Kecamatan Karas Kabupaten Magetan).

Nelfi Sarlis. 2018. Faktor Berhubungan Dengan Status Gizi Balita Di Puskesmas Sidomulyo Pekanbaru Tahun 2016.

Siti Indriyani Safitri. 2018. Hubungan Antara Sikap Dan Pengetahuan Ibu Dengan Status Gizi Berdasarkan BB/U Pada Anak Balita Di Wilayah Kerja Puskesmas Kota Singkawang.

Notoatmodjo, 2010. Faktor Faktor Yang Mempegaruhi Status Gizi. Erlanga: Jakarta. 
Sufren, Naraneal.2014. Belajar Otadidak SPSS Pasti Bisa .Gramedia: Jakarta

Notoatmodjo, S. 2012. Metodelogi Penelitaian Kesehatan. Rineka Cipta . Jakarta.

Julita Nainggolan, 2019. Hubungan Antara Pengetahuan Dan Sikap Gizi Ibu Dengan Status Gizi Balita Di Wilayah Kerja
Puskesmas Rajabasa Indah Kelurahan Kelurahan Rajabasa Raya Bandar Lampung. Nurmaliza , 2018. Hubungan Pengetahuan Dan Pendidikan Ibu Terhadap Status Gizi Balita.

Mubarak, 2018. Analisis Faktor yang Berhubungan dengan Status Gizi Anak Balita di Wilayah Pesisir Kecamatan Soropia 